\title{
Anterior Mediasten Yerleşimli Ektopik Paratiroid Adenomuna Bağlı Primer Hiperparatiroidizm Olgusu
}

\section{A Case Of Primary Hyperparathyroidism Due To Anterior Mediastinum Located Ectopic ParathyroidAadenoma}

\author{
Akif Acay ${ }^{1}$, Beray Çoker ${ }^{1}$, Ufuk Özuğuz ${ }^{2}$, Şule Gülşah Yağc1 ${ }^{3}$
}

\begin{abstract}
${ }^{1}$ Afyon Kocatepe
Üniversitesi Tıp Fakültesi, İç Hastalıkları Anabilim Dalı, Afyonkarahisar

${ }^{2}$ Afyon Kocatepe

Üniversitesi Tıp Fakültesi,

Endokrinoloji ve

Metabolizma Hastalıkları

Bilim Dalı, Afyonkarahisar

${ }^{3}$.Afyonkarahisar Devlet

Hastanesi, Nükleer Tip

Kliniği, Afyonkarahisar
\end{abstract}

\section{Corresponding Author:}

Dr.Akif Acay

\section{Address:}

\section{Afyon Kocatepe}

Üniversitesi Tıp Fakültesi,

İç Hastalıkları Anabilim

Dalı, Afyonkarahisar

\section{E-mail:}

drakifacay@gmail.com

Mobile: 905055066064

Başvuru Tarihi/Received :

10-11-2014

Kabul Tarihi/Accepted:

\section{ÖZET}

Amaç: Paratiroid adenomlarının \%5-10’u ektopik yerleşimlidir ve sırasıyla \%95'i timus içinde, $\% 5^{\prime} \mathrm{i}$ ise mediastende lokalizedir. Burada, primer hiperparatiroidi kliniği ile başvurmuş ön mediasten yerleşimli ektopik paratiroid adenomu olan bir olguyu sunmayı amaçladık.

Olgu: Kırkaltı yaşında kadın hastanın yapılan kan tetkiklerinde, kalsiyum: $11,6 \mathrm{mg} / \mathrm{dl}$ (8.5-11.0), fosfor: 1,4 mg/dl (2.8-5.0), 25-OH D Vitamin düzeyi 4,5 ng/ml, Parathormon: 696 pg/ml (12-72) saptandı. Ayrıca, hastaya çekilen paratiorid sintigrafisinde; ön mediasten orta hatta paratiroid adenomuyla uyumlu yoğun patolojik aktivite tutulumu ve çekilen toraks BT'sinde aynı lokalizasyonda $28 \times 20 \mathrm{~mm}$ boyutlarında ektopik paratiroid adenomu tespit edildi. Tedavi olarak video endoskopik yöntemle paratiroid adenomunun lokalizasyonu tespit edilip, adenom sternum dışına timüs ile birlikte çıkarıldı (Ektopik paratiroidektomi ve timektomi).

Sonuç: Paratiroid adenomlarında cerrahi en etkili tedavi seçeneğidir ve nadir de olsa glandların ektopik yerleşebileceği göz ardı edilmemelidir. Cerrahi başarı ise büyük oranda bezin lokalizasyonunun preoperatif belirlenmesine bağlıdır. Adenomu

Anahtar Kelimeler: Primer Hiperparatiroidizm, Ektopik Paratiroid

\section{ABSTRACT}

Purpose: Ectopically located parathyroid adenomas are seen in $5-10 \%$ of the patients and these are located in thymus and in the mediastinum with the rates of $95 \%$ and $5 \%$, subsequently. Here, we aimed at presenting a patient with an anterior mediastinum located parathyroid adenoma that was admitted with primary hyperparathyroidism.

Case report: In the blood serum analysis of the 46 years old female patient; calcium $(\mathrm{Ca}+)$ level was defined as $11,6 \mathrm{mg} / \mathrm{dl}(8.5-11.0)$, phosphorus level as 1,4 $\mathrm{mg} / \mathrm{dl}$ (2.8-5.0), 25-OH vitamin D level as $4,5 \mathrm{ng} / \mathrm{ml}$ and parathyroid hormone (PTH) level was as $696 \mathrm{pg} / \mathrm{ml}(12-72)$.

In addition, on parathyroid scintigraphy there was an intense activity involvement on the anterior midline mediastinal region and on computerized tomography; a $28 \mathrm{~mm}$ sized ectopic parathyroid gland at the same location was reported. An endoscopic surgery was performed and the thymus and parathyroid adenoma were removed out of the sternum (ectopic parathyroidectomy with thymectomy).

Result: The most effective therapy for ectopic parathyroid adenomas is surgery and although they are seen rarely, it should be kept in mind that parathyroid glands may be present in ectopic locations. The success of the surgery is mostly depends on the preoperative localization of this ectopic gland.

Keywords: Primary Hyperparathyroidism, Ectopic Parathyroid Adenoma 


\section{GİRIŞ}

Paratiroid bezleri salgıladıkları parathormon (PTH) aracılığı ile kalsiyum ve kemik metabolizmasının düzenlenmesinde önemli role sahiptirler. Anatomik olarak boyunda tiroid bezinin hemen arkasında altta ve üstte ikişer adet olmak üzere, genellikle dört adetdir. Alt paratiroid bezleri, embriyonel gelişim sırasında timusla beraber göç etmektedir. Embriyolojik olarak uzun göç yolundan dolayı, alt paratiroid bezlerinde üstteki paratiroid bezlerine kıyasla ektopik yerleşim daha $\mathrm{s} 1 \mathrm{k}$ görülmektedir. $\mathrm{Bu}$ ektopik yerleşim karotis bifurkasyonundan perikarda kadar birçok bölgede olabilir $(1,2)$. Primer hiperparatiroidizm, paratiroid bezinden aşırı parathormon üretiminin olduğu, klinik olarak hiperkalsemi, hipofosfatemi ve aşırı kemik rezorpsiyonu ile seyreden bir hastalıktır. Primer hiperparatiroidi'nin en sik sebebi paratiroid adenomu olup (\%85) daha nadir olarak paratiroid hiperplazisi (\%13) ve paratiroid karsinomlarından (\%1-2) kaynaklanabilir (3). Paratiroid adenomları büyük oranda normal anatomik yerleşimlerinde tiroidin hemen arkasında görülmektedir. Bununla birlikte \%5-10 vakada ektopik yerleşim billdirilmektedir. Ektopik paratiroid adenomlarının $\% 95$ ' $\mathrm{i}$ timus içinde, \% 5' $\mathrm{i}$ ise mediasten içindedir (4). Bu makalede ender rastlanan, PHPT kliniği ile başvurmuş ön mediasten yerleşimli ektopik paratiroid adenomu olan bir olguyu sunuyoruz.

\section{OLGU}

Kırkaltı yaşında kadın hasta, diz ağrısı şikayeti ile gittiği fizik tedavi ve rehabilitasyon polikliniğinde yapılan rutin kan tetkiklerinde, kalsiyum: $11.6 \mathrm{mg} / \mathrm{dl}$ (8.5-11.0), fosfor: $1.4 \mathrm{mg} / \mathrm{dl}$ (2.8-5.0), 25-OH D Vitamin düzeyi $4.5 \mathrm{ng} / \mathrm{ml}$, PTH: $696 \mathrm{pg} / \mathrm{ml}$ (12-72) saptanmas1 üzerine primer hiperparatiroidi tanısı ile etyolojik neden araştırılması için polikliniğimize yönlendirilmiş.

Hastaya adenom lokalizasyonu için yapılan boyun ultrasonografisinde, tiroid normal boyutlarda olup istmusta $7.5 * 11 * 10 \mathrm{~mm}$ boyutlarında parankimden sinırları net ayırt edilemeyen mikrokalsifikasyonlar içeren izo-hipoekoik nodül saptand1. Ancak bilateral tiroid lojunda paratiroid adenomu ile uyumlu lezyon saptanmadi. Hastaya çekilen paratiorid sintigrafisinde ise; ön mediasten orta hatta paratiroid adenomuyla uyumlu yoğun patolojik aktivite tutulumu ve tiroid bezi sağ lob orta kesim posteriorunda hafif lokal aktivite artış1 saptand1 (Resim1,2).

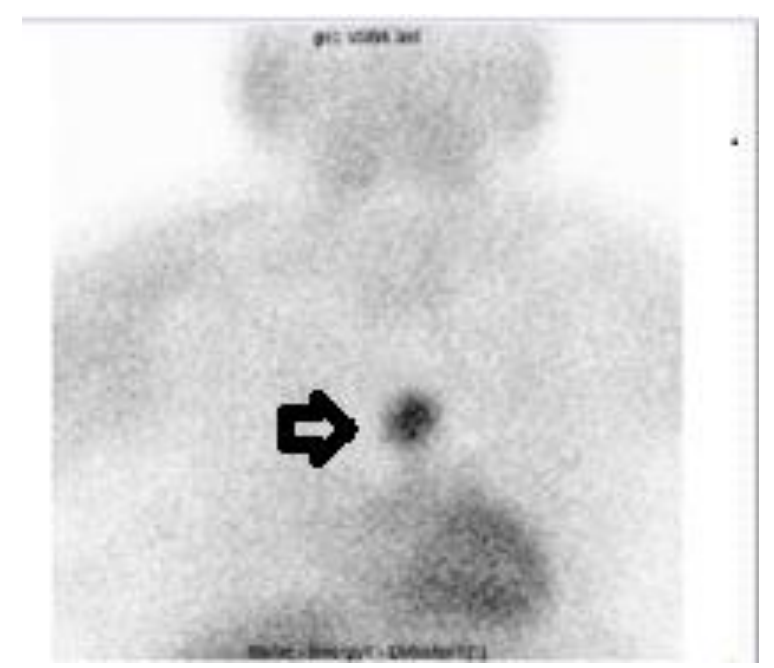

Resim 1 Mediasten yerleşimli adenomun önden sintigrafik görüntüsü.

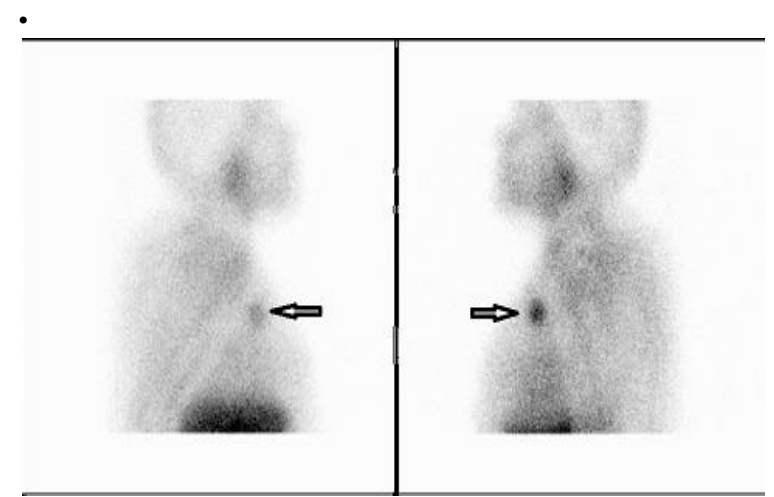

Resim 2 Anterior mediasten yerleşimli adenomun yandan sintigrafik görüntüsü

Bunun üzerine hastadan adenomu anatomik olarak görüntüleyebilmek için toraks bilgisayarlı tomografisi (BT) çekildi. Toraks BT'de anterior mediastende retrosternal alanda $28 \times 20 \mathrm{~mm}$ boyutlarında yoğun kontrastlanan nodüler lezyon (ektopik paratiroid adenomu?)" saptand1 (Resim 3). 


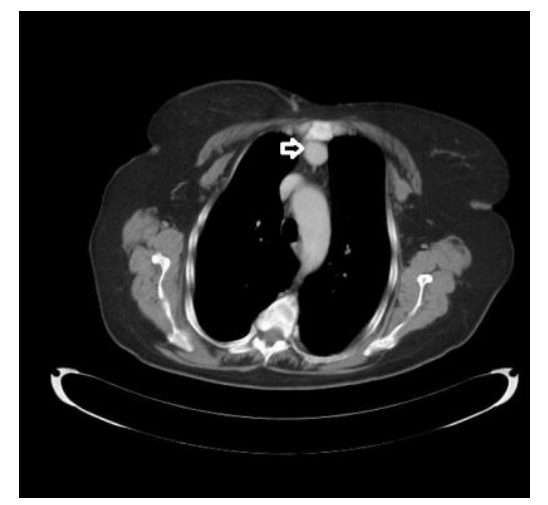

Resim 3 Anterior mediasten yerleşimli adenomun toraks BT görünümü.

Hastanın özgeçmişinde hipertansiyon, bronşial astım ve sol böbrekte taş öyküsü mevcuttu. Yapılan kemik dansitometre ölçümünde, L1-L4 T skoru: - 3.5 ve femur boynu T skoru:-4 olarak saptandı. Hiperkalsemi varlığı, osteoporoz ve nefrolitiazis öyküsü nedeni ile hastaya cerrahi tedavi (paratiroid adenomektomi) planlandı.

Cerrahi olarak, video endoskopik yöntemle paratiroid adenomunun lokalizasyonu tespit edildikten sonra, adenom sternum dışına timus ile birlikte çıkarıldı (Paratiroid adenomektomi + timektomi). Postoperatif 3. günde serum Ca ve PTH düzeyleri normal düzeylere gerileyen hasta sorunsuz bir şekilde taburcu edildi.

\section{TARTIŞMA}

Primer hiperparatiroidi, ayaktan başvuran hastalarda hiperkalseminin en s1k nedenidir. Parathormon düzeyinin yüksek olması nedeni ile diğer hiperkalsemi yapan sebeplerden kolayca ayrılabilir. Parathormon fizyolojik olarak , kemikten kalsiyum mobilizasyonu yapar. Böbrekte tübüllerden kalsiyum emilimini artırırken fosfor atılımını artırmaktadır. Barsak üzerindeki etkisi ise indirekt olarak D vitamini üzerinden olup kalsiyum ve fosfor emilimini artırmaktadır (5). Primer hiperparatiroidi hastalarında başlıca laboratuvar bulgular1; hiperkalsemi, hiperkloremi, hipofosfatemi, hiperkalsiüri, artmış alkalen fosfataz ve artmış üriner hidroksiprolin düzeyleridir. Primer hiperparatiroidi vakaları sıklıkla asemptomatiktir. Semptomatik hastalarda ise kas-iskelet sistemi bulguları (osteitis fibrosa kistika (Brown tümörü), subperiosteal rezorpsiyon, patolojik kırıklar, kemik ağrıları, kemik deformiteleri), böbrek taşları ve gastrointestinal bulgular (bulant1-kusma, peptik ülser ve konstipasyon) görülebilir (6). Bizim hastamızda klinik bulgular olarak nefrolitiazis öyküsü ile birlikte lomber vertebralarda ve femurda ciddi osteoporoz mevcuttu. Primer hiperparatiroidi'nin en s1k sebebi $(\% 85)$ paratiroid adenomu iken, bu adenomların \%5-10'u kadarı ektopik yerleşimlidir $(3,4)$. Boyun ultrasonu ile çoğu zaman paratiroid adenomlarının lokalizasyon tespit edilebilse de, özellikle ektopik adenomlar için toraks BT ve magnetik rezonans görüntüleme gerekebilir. Ektopik paratiroid dokusunun tanımlanmasında en etkili görüntüleme yöntemi teknesyum-99m sestamibi (Tc-99m sestamibi) sintigrafisidir $(7,8)$. Bizim hastamızda da, boyun ultrasonu ile adenomu tespit edemediğimiz için toraks BT ve Tc-99m sestamibi sintigrafisi ile ektopik adenomu ortaya koyabildik. Paratiroid adenomlarında cerrahi ile adenomun çıkarılması temel tedavi yöntemidir. Ancak özellikle adenomun lokalizasyonuna bağlı olarak cerrahi yaklaşım değişmektedir. Çoğunlukla tiroid inferiorunda veya servikal bölgede yerleşmiş lezyonlar servikal yaklaşım ile çıkarılırken, üst mediastinal adenomlar total veya parsiyel sternotomi ile çıkarabilir. Ancak 2 cm'den küçük nodüller eksplorasyonda bulunamadığı durumlarda, intraoperatif gamma probe ile cerrahi rezeksiyon sağlanabilir (9). Cerrahi ile ilgili bir başka önemli nokta, özellikle anterior veya posterior yerleşimli lezyonlar için video yardımlı torakoskopik cerrahinin (VATS) bir başka alternatif olabileceğidir (10). Son y1llarda literatürde paratiroid adenomları için cerrahi dışı tedavi olarak, alkol ve sklerozan ajanlar ile adenom ablasyonu yapılabilmekte ve etkili sonuçlar alındığından bahsedilmektedir (11). Hastamıza ise, paratiroid adenomunun kesin lokalizasyonu sağlandıktan sonra video endoskopik yöntemle, adenom sternum dışına timüs ile birlikte çıkarıldı (Paratiroid adenomektomi + timektomi). Cerrrahi sonrasında hastaların kliniğinde belirgin bir düzelme olmaktadır. Başarılı yapılmış bir paratiroid adenomektomi sonrası, adale güçsüzlüğü, osteitis fibrosa kistika, böbrek taşı oluşumu ve kemik 
DOI: $10.16899 / \mathrm{ctd} .11839$

mineral yoğunluğu gibi birçok semptom ve bulguda düzelme görülmektedir.

Sonuç olarak paratiroid adenomlarında cerrahi en etkili tedavi seçeneğidir. Nadir de olsa adenomların ektopik yerleşebileceği göz ard1 edilmemelidir. Cerrahi başarı ise büyük oranda adenomun kesin lokalizasyonuna bağlıdır.

\section{KAYNAKLAR}

1. Lumachi F, Zucchetta P, Varotto S, Polistina F. Noninvasive localization procedures in ectopic hyperfunctioning parathyroid tumors. Endocr Relat Cancer 1999;6:123-5.

2. Caporale DM, Bobbio A, Accordino R, et al. Ectopic mediastinal parathyroid adenoma. Acta Biomed 2003;74:157-9.

3. Jaskowiak N, Norton JA, Alexander HR, et al. A prospective trial evaluating a standard approach to reoperation for missed parathyroid adenoma. Ann Surg 1996; 224: 308-22.

4. Geelhoed GW, Krudy AG, Doppmasnn JL. Long-term fol- low-up of patient with hyperparathyroidism treated by transcatheter staining with contrast agent. Surgery 1983; 94: 849-62.
5. Ariyan CE, Sosa JA. Assessment and management of patients with abnormal calcium. Crit Care Med 2004;32:146-54.

6. Dionisi S, Minisola S, Pepe J, et al. Concurrent parathyroid adenomas and car- cinoma in the setting of multiple endocrine neoplasia type 1: presentation as hypercalcemic crisis. Mayo Clin Proc 2002;77:866-9.

7. Ogawa T, Tsuji E, Kanauchi $\mathrm{H}$, et al. Excision of postesophageal parathyroid adenoma in posterior mediastinum with intraoperative 99mTechnetium sestamibi scanning. Ann Thorac Surg 2007;84:1754-6.

8. Murat Kara, Adem Güngör. A case of primary hyperparathyroidism secondary to ectopic parathyroid adenoma located in thymus. Tuberk Toraks 2001;49:497-9

9. Doğan R, Kara M, Yazicioğlu A, Kaynaroğlu V. The use of gamma probe for the intraoperative localization of an ectopic parathyroid adenoma. Tuberk Toraks 2009;57:20811.

10. Amar L, Guignat L, Tissier F, et al. Video-assisted thoracoscopic surgery as a first-line treatment for mediastinal parathyroid adenomas: strategic value of imaging. Eur J Endocrinol 2004;150:141-7.

11. Cook GJ, Fogelman I, Reidy JF. Successful repeat transcatheter ablation of a mediastinal parathyroid adenoma 6 years after alcohol embolization. Cardiovasc Intervent Radiol 1997;20:314-6. 